\title{
Multi-Analytical Investigation of Stains on Dimension Stones in Master Valentim's Fountain, Brazil
}

\author{
Roberto Carlos da Conceição Ribeiro *D, Patrícia Marques Ferreira de Figueiredo and \\ Daniel Silva Barbutti \\ Centre for Mineral Technology (CETEM), Av. Pedro Calmon 900, Cidade Universitária, \\ 21941-908 Rio de Janeiro, Brazil; patriciamff@yahoo.com.br (P.M.F.d.F.); danielbarbutti@gmail.com (D.S.B.) \\ * Correspondence: rcarlos@cetem.gov.br; Tel.: +55-21-3865-7264
}

Received: 6 August 2018; Accepted: 12 October 2018; Published: 18 October 2018

\begin{abstract}
Master Valentim's fountain has become an important historical patrimony for Brazil, being portrayed by famous artists, among them Jean-Baptiste Debret. In 1938, it was registered as cultural heritage by the Brazilian National Historical and Artistic Heritage Institute (IPHAN), and in 1990 it was subjected to excavation and restoration works. The fountain was built in Gneiss and Lioz limestone, with metallic plates and mortar connecting the Gneiss blocks. Currently, deteriorations in the fountain stones can be observed, such as light stains and some aesthetic modifications caused by inadequate restorations. Petrography, X-ray fluorescence (XRF), XRD, physical properties, colorimetry, electrical conductivity, inductively coupled plasma optical emission spectrometry (ICP-OES), scanning electron microscopy-energy dispersive X-ray (SEM-EDX), and TGA were performed in order to characterize the Gneiss blocks, the metallic plates, and the stones used in previous restorations, as well as light stains observed on the Gneiss blocks. The petrography and XRD analyses inferred that the light stains may have been caused by the formation of an insoluble salt as a result of the association of the lead from the plates with other elements. The XRD analysis on the light staining area indicated the presence of cerussite $\left(\mathrm{PbCO}_{3}\right)$ and anglesite $\left(\mathrm{PbSO}_{4}\right)$, which are the probable cause of the light stains. The SEM-EDX results suggested that sulfur is the main element associated to lead.
\end{abstract}

Keywords: Master Valentim's fountain; Gneiss; Lioz limestone; conservation and restoration

\section{Introduction}

\subsection{Master Valentim's Fountain}

Currently, fountains are generally associated with aesthetic components. Nevertheless, they were initially built with the purpose of a water supply source. The fountain designed by Carlos Mardel is an example of this. It was inaugurated in 1747 at Terreiro do Paço in downtown Rio de Janeiro, Brazil (area known as Praça XV de Novembro nowadays) [1,2]. In 1789, because of the distance from the sea, a new fountain was built closer to the port as a substitute for the original one. The artist responsible for the new fountain was called Valentim da Fonseca e Silva, better known as Master Valentim. The intention was to attend to the demand from sailors and from the city, transforming the place into the main entrance for travelers that arrived by ship [3]. At the beginning of the 20th century, after losing its usefulness as a water source, the fountain became an important monument, which was recognized as cultural heritage by the Brazilian National Historical and Artistic Heritage Institute (IPHAN) in 1938. The fountain had its urban condition recovered in the 1990s, through a work of excavation and restoration that revealed the original staircase and berth [1]. 
The architecture of "Master Valentim's fountain" (Figure 1), as it is commonly called, was inspired by Rococo, the last phase of the Baroque period, that emerged in France in the mid-1700s [4]. The fountain was built in Gneiss and Lioz limestone [5]. To connect the Gneiss blocks and other blocks of the monument, Master Valentim applied his expertise in the manipulation of molten metals [6].

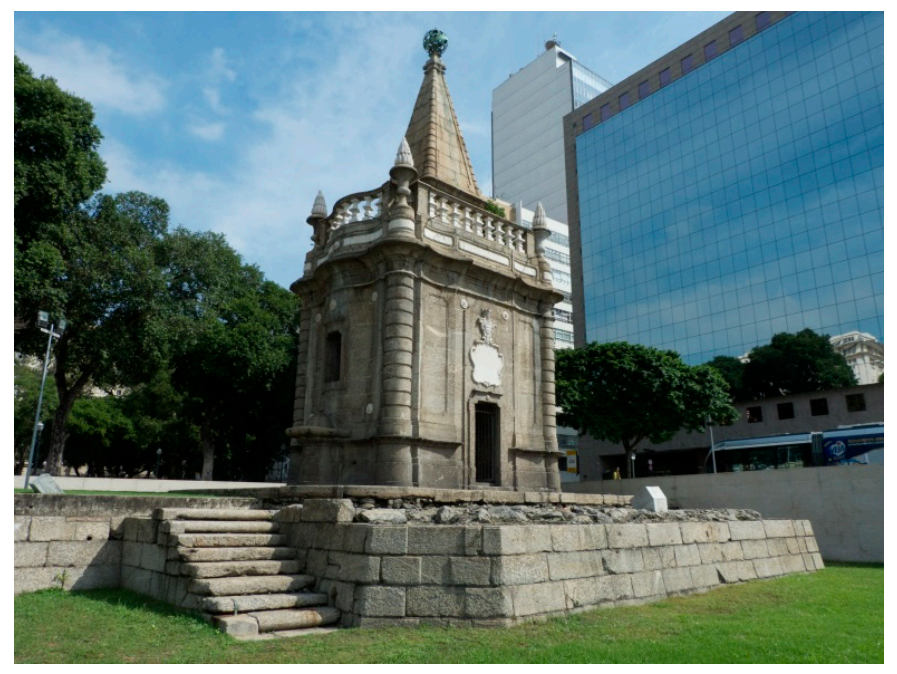

Figure 1. Master Valentim's fountain, located in Rio de Janeiro, Brazil.

The fountain can be seen in artistic productions of the famous French painter Jean-Baptiste Debret, as shown in Figure 2. In this work of art, Debret portrayed Praça XV de Novembro in the 19th century, and the Master Valentim's fountain can be seen in the background.

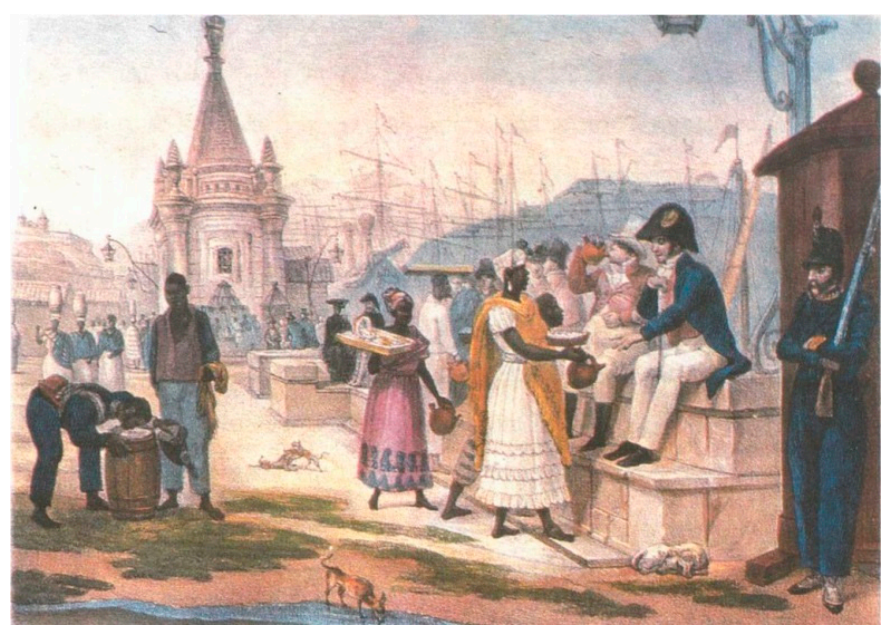

Figure 2. Debret's work of art named "An afternoon at the Palace Square" (1826) [7].

\subsection{Phacoidal Gneiss}

The city of Rio de Janeiro is known for its natural beauty. Mountains that plunge into the sea make the city a postcard of Brazil that, together with the spirit of solidarity and joy of its people, gave it the title of the Wonderful City. Most of the monuments found in the city are made of a specific type of rock, the "phacoidal gneiss" (Figure 3), that is responsible for the construction of the city and the cultural aspects that shaped its people and transformed its landscape into a tourist icon for the country. The Carioca landscape that enchants everyone, from the naturalists who visited Brazil in the XVIII and XIX centuries to the tourists of today, is closely related to "phacoidal gneiss", a rock that is very resistant to weathering and that, for this reason, stands out in the relief, giving shape to the Sugar 
Loaf and the Corcovado, for example. It was used in the construction of most of the city's historical monuments in the form of ornaments, facades, and door and window frames, as well as the curb of the oldest part of the city. The use of "phacoidal gneiss" in stonework was described by Jean Baptiste Debret in his book "Picturesque and Historical Journey to Brazil", where he explains that it is softer, less expensive, and easily exploitable, being destined for the parts of the buildings that should be sculpted. This rock is still present in important landmarks in the history of Brazilian art, for example, the Candelária church and S. Bento's Monastery (Figure 4A,B). It was in "Pedra do Sal", a staircase carved in phacoidal gneiss, that the negroes gathered to tell stories, perform religious services, and sing. From these meetings at "Pedra do Sal", the samba was born [8].

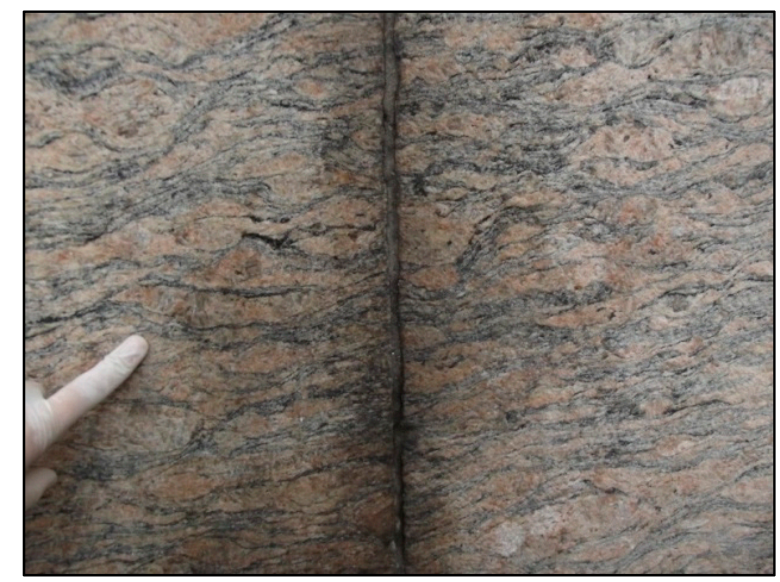

Figure 3. Phacoidal gneiss.

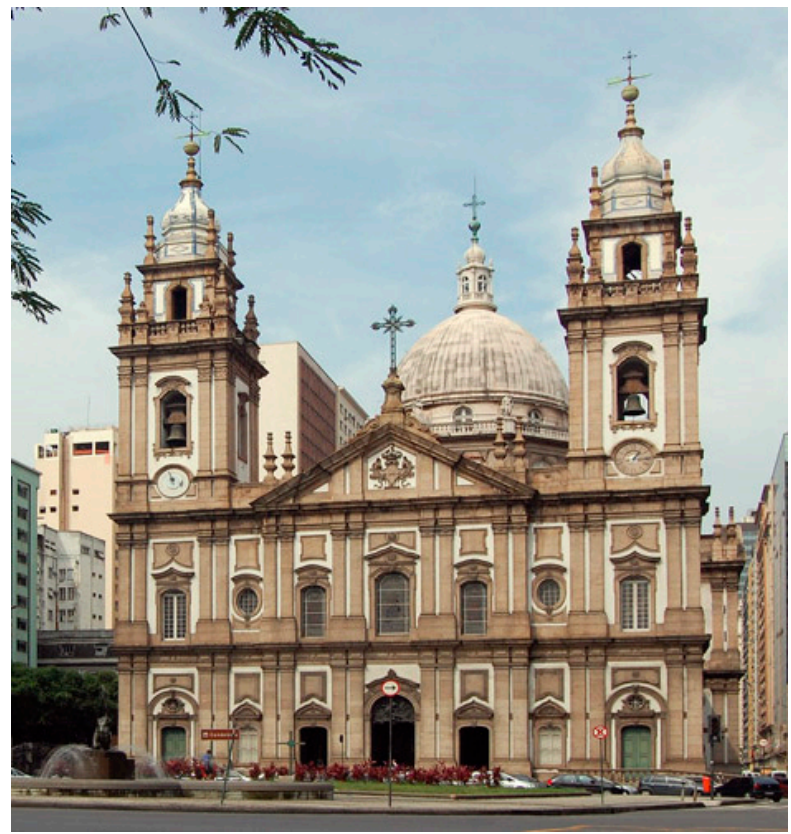

(A)

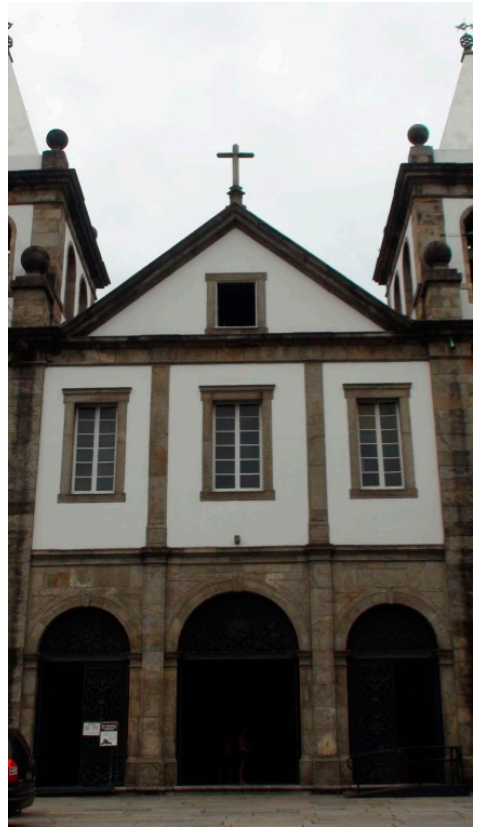

(B)

Figure 4. (A): Candelária church; (B): S. Bento Monastery.

\subsection{Alterability in Dimension Stone Monuments}

Stone monuments located in open areas are vulnerable to physical, chemical, mechanical, and biological weathering that contributes to the alteration of their structural properties [9]. The in-depth knowledge of the mechanisms that promote such deteriorations is essential to provide adequate conservation and restoration actions for dimension stones. 
Exposure to atmospheric conditions including air pollution results in the complex and natural process of stone ageing [10]. In urban environments, among the various weathering effects on stone, black crusts, efflorescence, and staining are certainly the most visible and the most studied [11,12]. Black crusts are extremely common in polluted urban environments; these sulphate encrustations can developed on all types of materials $[13,14]$.

Salts, and particularly sodium sulphate, are known to be among the most destructive agents in porous stones, and cause staining on the stones, in addition to the internal destruction of the rock due to the accumulation of salt. The study of its crystallization mechanism is therefore very important to fully understand its damage on porous networks [15].

In Rio de Janeiro, due to atmospheric pollution and proximity to the sea, monuments are constantly degraded, with black crust formation (Figure 5A) and efflorescence (Figure 5B) being observed.

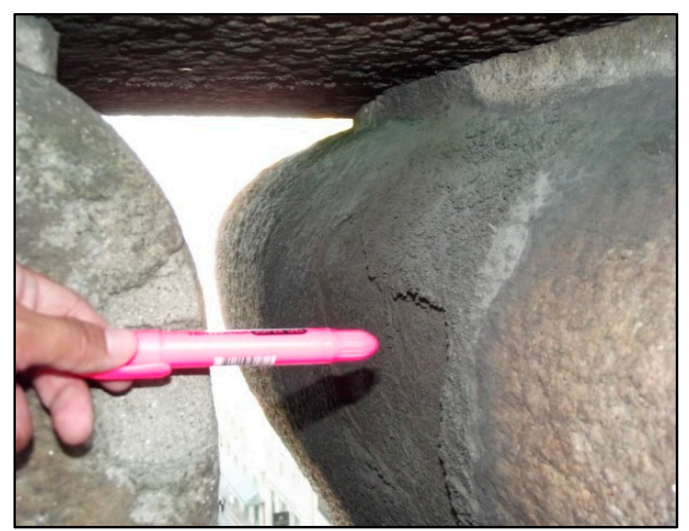

(A)

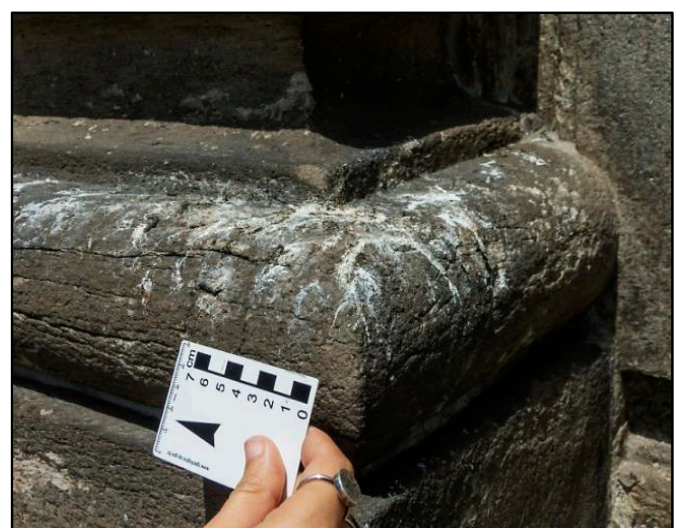

(B)

Figure 5. (A): Black crust in gneiss; (B): Efflorescence in gneiss.

Nowadays, it is possible to observe deteriorations in the fountain stones, among them light stains on the Gneiss blocks, besides some inadequate aesthetic modifications. The white stains found in the fountain indicated an apparent alterability caused by $\mathrm{NaCl}$, but after verification of insolubility in water, it was observed that it was a more specific stain. Thus, the objective of this work is to characterize the white spots observed in the stones of Master Valentim's fountain and its possible causes.

\subsection{Importance of Technological Support in Restoration}

The characterization of the dimension stones or mortars is very important because it characterizes the material, and determines the causes of changes and methods of action to curb the degradation of the monument [16]. Several places in the world have already had their stones or mortars characterized, including those from the Byzantine period from the sixth to the tenth centuries [16].

Many techniques have been successfully applied in the characterization, including X-ray diffraction [17-29], macroscopic observation [28], petrography [28,29], physical analysis [28], infrared spectroscopy [16,20], chemical analysis [26-28], thermogravimetric analysis (TG-DTG) [16-28], mechanical tests [20], and granulometry [16,28,29].

\section{Materials and Methods}

A gneiss fragment containing the white spot for evaluation, and a further spotless fragment, was used. Both measured about $3 \mathrm{~cm} \times 3 \mathrm{~cm} \times 1 \mathrm{~cm}$. For this, the following analyses were performed: Petrography, X-ray fluorescence (XRF), X-ray diffraction (XRD), physical properties, colorimetry, electrical conductivity, inductively coupled plasma optical emission spectrometry (ICP-OES), scanning electron microscopy-energy dispersive X-ray (SEM-EDX), and thermogravimetric analysis (TGA). All tests were carried out in the laboratories of the Centre of Mineral Technology-CETEM, Rio de Janeiro-RJ, Brazil. 


\subsection{Petrography}

Macroscopic and microscopic analyses were carried out on a fragment of a Gneiss block by means of an optical microscopy. The sample was described using a Schneider magnifying glass with a Carl Zeiss lens (COPAL, Bietigheim-Bissingen, Germany) zoomed in from $6.5 \times$ to $60 \times$, and fluorescent light.

\subsection{X-ray Fluorescence (XRF)}

Chemical analyses through XRF were performed on areas where the Gneiss stones had light staining, and in a connection plate of the monument that was provided for study.

For the connection plate, a benchtop PANalytical Axios ${ }^{\mathrm{mAX}}$ (Axios Max, The Analytical X-ray, Malvern Panalytical, Almelo, The Netherland) $4.0 \mathrm{~kW}$ was used. The semi-quantitative omnian calibration standard was applied, with voltage and current ranges of $25-60 \mathrm{kV}$ and $66-160 \mathrm{~mA}$, respectively, time analyses, $20 \mathrm{~min}$; gas: Argon; gas pressure, $600-1300 \mathrm{hPa}$; gas flow, $0.5-3.0 \mathrm{~L} \mathrm{~h}^{-1}$; vacuum, $1.14 \mathrm{~Pa}$; cabinet temperature, $29-30^{\circ} \mathrm{C}$; and $\mathrm{RX}$ tube power, $50 \mathrm{kV}$ and $60 \mathrm{~mA}$.

For the stains, the analyses were made in situ by means of a portable Bruker S1 TURBO SD spectrometer (Bruker elemental, Kennewick, Washington, DC, USA) with a Silicon Drift Detector (SDD), maximum voltage of $40 \mathrm{kV}$, and maximum anode current of $60 \mu \mathrm{A}$ (the maximum high-voltage available at $60 \mu \mathrm{A}$ is $15 \mathrm{kV}$ ). The analyses were performed using the Universal mode, which is the default analysis type, and works with automatic method detection and Dual Energy excitation.

\subsection{X-ray Diffraction (XRD)}

The mineralogical compositions of a fragment of a Gneiss block and a small portion of the light staining area collected at the site were evaluated. The XRD analyses were performed on a Bruker-AXS D4 Endeavor diffractometer (D8 Endeavor, Ettlinger, Germany), with Co k $\alpha$ radiation $(40 \mathrm{kV}, 40 \mathrm{~mA})$. Diffraction patterns were acquired from 4 to $80(2 \theta)$ at 0.02 steps. The identification of all minerals was done with Bruker-AXS's DIFFRAC.EVA suite.

\subsection{Physical Properties}

Tests were carried out based on the ABNT NBR 15845-2 to evaluate the porosity and water absorption of the Gneiss fragment. Measurements were taken at atmospheric pressure by a Marte AD2000 hydrostatic balance (Marte Científica, Belo Horizonte, MG, Brazil).

\subsection{Colorimetry}

A portable BYK spectrophotometer (Spectro-Guide Sphere Gloss, Spectro Guide 6834/1094042, Geretsried, Germany) was used to evaluate the color and gloss of the original stones and of those used in the restorations, as well as the stains mentioned previously. The colorimeter operates with a $400-700 \mathrm{~nm}$ spectral range and $10 \mathrm{~nm}$ spectral resolution.

The results were expressed on CIELAB three-dimensional color space reference (Figure 6), where the $L^{*}$ axis represents the lightness of a color from the darkest black $\left(L^{*}=0\right)$ to the brightest white $\left(L^{*}=100\right)$; the $a^{*}$ axis indicates the greenness or redness of a color, with $a^{*}<0$ representing green, whereas $a^{*}>0$ represents red; and the $b^{*}$ axis expresses blue and yellow opponent colors, with negative values of $b^{*}$ for blue, and positive values of $b^{*}$ for yellow. Consequently, when the values of $a^{*}$ and $b^{*}$ are equal to zero, true neutral gray is expressed [30].

All colorimetric measurements for the original stones (used as control), and for altered or substitute stones, were performed in quadruplicates. 


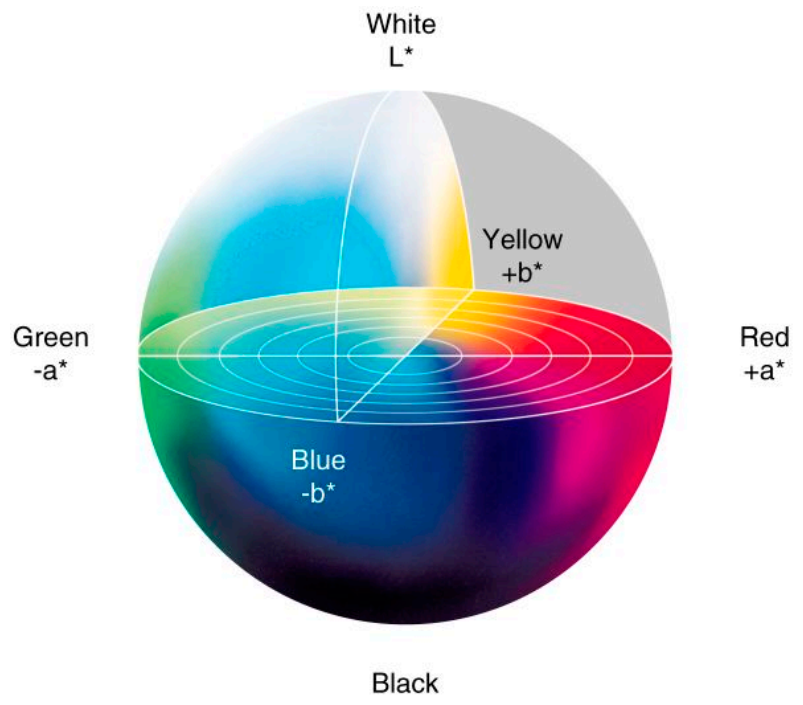

Figure 6. Representation of the CIELAB coordinates [30].

\subsection{Electrical Conductivity}

The conductivity tests were carried out with the Gneiss fragment. It was immersed in distilled water for approximately $120 \mathrm{~h}$. Afterwards, the water conductivity was analyzed with the assistance of TECNOPON portable equipment (model mCA-150P, Tecnopon 150uCA, São Paulo, Brazil). For this, a standard solution of $146.9 \mu \mathrm{S} / \mathrm{cm}$ was used at a reference temperature of $25^{\circ} \mathrm{C}$.

\subsection{Inductively Coupled Plasma Optical Emission Spectrometry (ICP-OES)}

ICP-OES was performed to quantify the possible elements present in the water that was analyzed by electrical conductivity. The following elements were quantified: sodium ( $\mathrm{Na})$, aluminum $(\mathrm{Al})$, potassium $(\mathrm{K})$, calcium $(\mathrm{Ca})$, iron $(\mathrm{Fe})$, magnesium $(\mathrm{Mg})$, and sulfur $(\mathrm{S})$. For this determination, a spectrometry Varian Spectra AA 55B (Varian Australia PTY, Sydney, Australia) was used. All samples were diluted 50-fold and 100-fold with distilled water. The conditions were: RF power, $1.500 \mathrm{~W}$; plasma argon flow, $15 \mathrm{~L} \mathrm{~min}^{-1}$; and nebula argon flow, $0.42 \mathrm{~L} \mathrm{~min}^{-1}$. Limits of detection were: $\mathrm{Na}$, $0.01470 \mathrm{mg} \mathrm{L}^{-1} ; \mathrm{Al}, 0.00904 \mathrm{mg} \mathrm{L}^{-1} ; \mathrm{K}, 0.03887 \mathrm{mg} \mathrm{L}^{-1} ; \mathrm{Ca}, 0.00542 \mathrm{mg} \mathrm{L}^{-1} ; \mathrm{Fe}, 0.0056 \mathrm{mg} \mathrm{L}^{-1} ; \mathrm{Mg}^{\prime}$ $0.00011 \mathrm{mg} \mathrm{L}^{-1}$; and $\mathrm{S}, 0.03568 \mathrm{mg} \mathrm{L}^{-1}$.

\subsection{Scanning Electron Microscopy-Energy Dispersive X-ray (SEM-EDX)}

The light staining area was also evaluated by means of SEM-EDX analyses. For this, a Hitachi scanning electron microscope (Model TM 3030 Plus, 55E-0063, Hitachi High-Technologies, Tokyo, Japan) was used. The instrument was equipped with a Bruker X-Flash energy dispersive X-ray spectrometer, with MIN SVE detector and scan generator connected.

\subsection{Thermogravimetric Analysis (TGA)}

TGA of the light staining, lead sulfate $\left(\mathrm{PbSO}_{4}\right)$, and lead carbonate $\left(\mathrm{PbCO}_{3}\right)$ samples was carried out for comparative purposes.

The analyses were performed using NETZSCH thermogravimetric equipment (model STA 409 PC Luxx, NETZSCH-Gerätebau GmbH, Selb, Germany). Approximately 12 mg samples were weighed in an aluminum crucible and heated between 40 and $560^{\circ} \mathrm{C}$ under a nitrogen atmosphere, with a flow rate of $50 \mathrm{~mL} \mathrm{~min}{ }^{-1}$ and a heating rate of $10{ }^{\circ} \mathrm{C} \mathrm{min}-1$. The residue at $500{ }^{\circ} \mathrm{C}$, the initial temperatures $\left(\mathrm{T}_{\text {onset }}\right)$, and the maximum temperatures $\left(\mathrm{T}_{\max }\right)$ - at which the degradation rate was maximum-were determined through the mass loss versus temperature curves. 


\section{Results and Discussion}

\subsection{Dimension Stones Characterization}

Macroscopically, the stone fragment sample is mesocratic, with a pinkish yellow color, medium to coarse grains, and a light band characterized by biotite segregation surrounding K-feldspar crystals. The sample showed signs of weathering effects, which were identified on the K-feldspars through the color change to yellowish and the fragmented condition that facilitates their breakdown. It was possible to observe a rich matrix in biotite that is vulnerable to oxidation, and fracturing zones visible to the naked eye.

Microscopically, the sample is characterized by granoblastic and porphyroblastic textures, and medium-to-coarse inequant grains, highlighting well-developed microcline and plagioclase crystals. The stone sample exhibited significant alterations and microcracks, which are often occupied by recrystallized quartz grains (Figure 7). The mineralogical composition is mainly quartz, K-feldspar, plagioclase, and biotite. The accessory minerals are muscovite, gamet, and opaque minerals $(\approx 1 \%)$. Sericite appears as an alteration mineral.

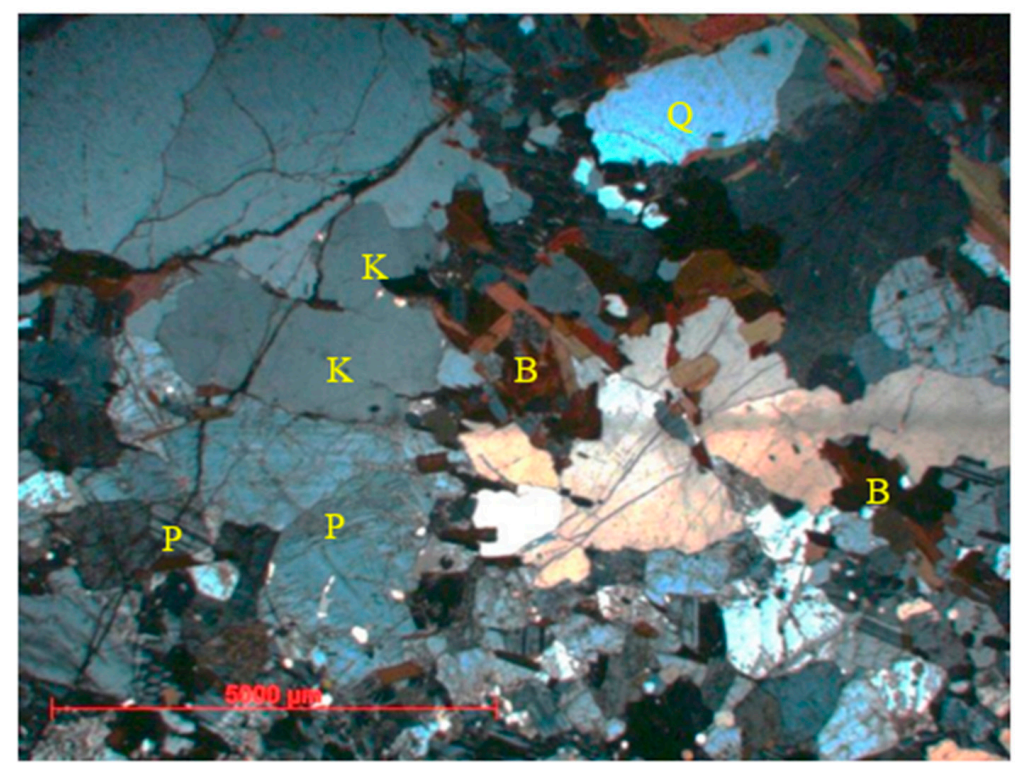

Figure 7. Photomicrograph of the stone sample taken by cross polarized light showing porphyroclastic texture and microcracks. Mineral abbreviations: Q, quartz; K, K-feldspar; P, plagioclase; and B, biotite.

The quartz crystals are anhedral, with varied sizes and incipient microcracks, as well as plate and sutured boundaries with other minerals. Stretched and recrystallized crystals were observed surrounding the plagioclase and microcline minerals.

The K-feldspar crystals (microcline) are subhedral and anhedral, with varied size (predominantly larger sizes), and diffuse chess-board twinning due to the alteration.

The plagioclase crystals are subhedral and anhedral, with varied size, as well as Albite and Albite-Carlsbad twinning.

Both the K-feldspar and plagioclase crystals showed significant alterations, with microcracks occupied by sericite. Moreover, it was possible to observe quartz intergrowth in these minerals.

The biotite crystals are subhedral, with reddish brown color, small size, and tabular shape. The crystals were disseminated throughout the slide and showed signs of deferrification due to the alteration.

The garnet crystals are subhedral and anhedral, exhibiting many microcracks.

The petrographic analysis allowed classification of the stone sample as Augen Gneiss. The sample showed microcracks and significant alterations that are possibly related to weathering effects. 
The XRD analysis indicated the presence of quartz, plagioclase, K-feldspar, mica, zircon, and titanite. Such a result is in agreement with the expectation for Gneiss stones according to the literature [10].

The XRF analysis on the Gneiss stone areas without stains showed values around $7 \%$ of lead $(\mathrm{Pb})$, $60 \%$ of silicon (Si), and $16 \%$ of aluminum (Al), with traces of other elements.

The electrical conductivity analysis performed in water, in which the Gneiss fragment was immersed, indicated a value of $44.17 \mu \mathrm{S} / \mathrm{cm}$ at $25.7^{\circ} \mathrm{C}$, confirming the presence of ions. Table 1 shows the quantitative results of these ions determined by ICP-OES analysis.

Table 1. ICP-OES result.

\begin{tabular}{cccccccc}
\hline Analytes & $\mathbf{N a}$ & $\mathbf{A l}$ & $\mathbf{K}$ & $\mathbf{C a}$ & $\mathbf{F e}$ & $\mathbf{M g}$ & $\mathbf{S}$ \\
\hline$\left(\mathrm{mg} \mathrm{L}^{-1}\right)$ & 2.1 & $<0.007$ & 0.81 & 3.5 & 0.01 & 0.43 & $<0.01$ \\
\hline
\end{tabular}

XRD analysis on the fragment of the Gneiss blocks identified minerals compatible with the expectation for Gneiss stones (quartz, plagioclase, K-feldspar, mica, zircon, and titanite). However, for the light staining area, this analysis also indicated the presence of cerussite $\left(\mathrm{PbCO}_{3}\right)$ and anglesite $\left(\mathrm{PbSO}_{4}\right)$. Moreover, XRF analysis on the staining area demonstrated higher content of lead $(\mathrm{Pb})$ than the one performed on the Gneiss stone area without stains. These results suggest that the light stains may have been caused by the association of the lead in the connection plates (confirmed by X-ray fluorescence analysis) with other elements (sulfur or carbon), forming an insoluble salt of white coloration.

Regarding the physical properties, porosity is one of the most important physical properties to evaluate the alterability of stones used in monuments, since this property is related to the stone's ability to absorb water (one of the most effective substances in stone weathering) [31]. The values of $1.0 \%$ and $0.4 \%$ are suggested as ideal for, respectively, porosity and water absorption of granites used as dimension stones [32,33]. The test performed on the Gneiss fragment indicated 3.36\% and $1.45 \%$ for porosity and water absorption, respectively. These results demonstrate that the Gneiss blocks are in a degradation process, since the values are higher than expected.

Colorimetric tests were performed to evaluate the replacement parts in previous restorations. It was easy to discern the original Gneiss stones from the replacement parts with the naked eye, since the latter were in a better polished state and were different colors (Figure 8). In the case of the restoration carried out on the Lioz limestone balustrade and torches (Figure 9), although the difference was more subtle, it was still perceptible. Regarding the gloss, the new pieces exhibited an increase in the values, but without relevance.

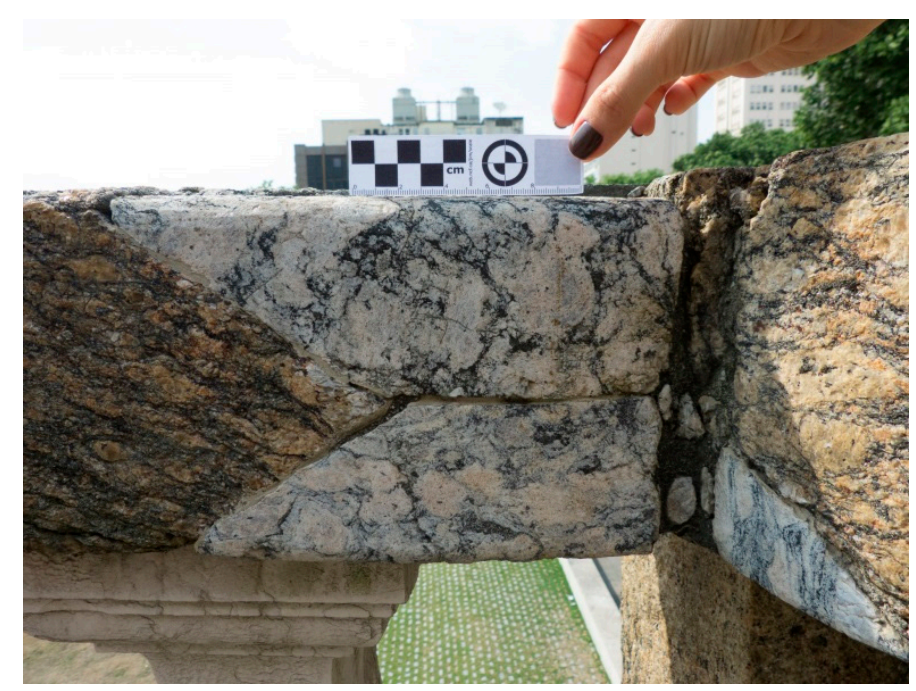

Figure 8. Substitute piece on a Gneiss block. 


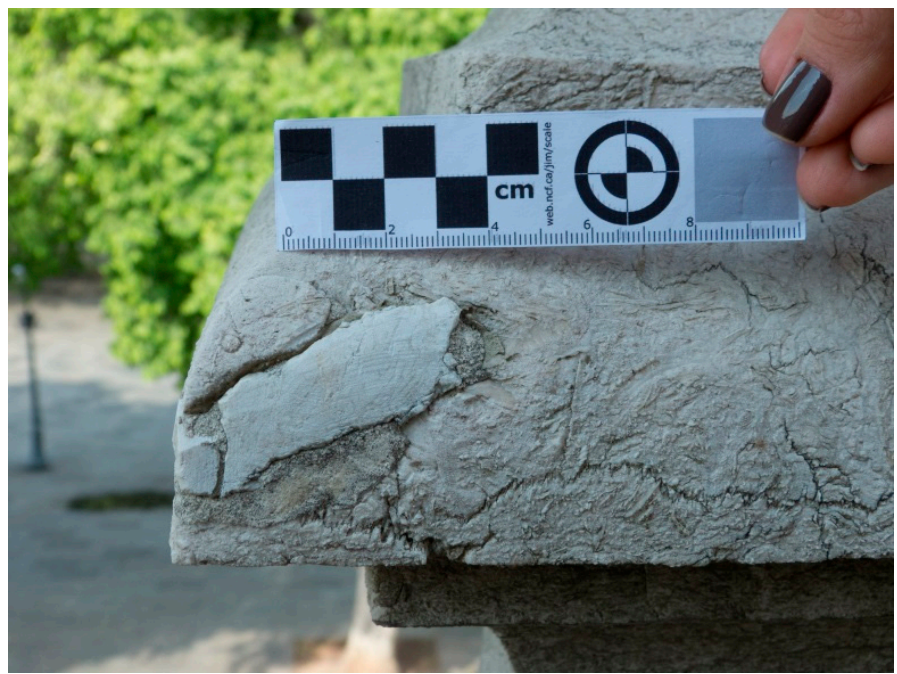

Figure 9. Lioz limestone area with restored part.

The analyses showed that the Lioz limestone is a light faded brown, and slightly orange, possibly due to the weathering effects. Nevertheless, there is chromatic compatibility between the new parts and a sound Lioz limestone. On the other hand, Gneiss showed a tendency to brown, with a more intense orange. The substitute stones for the Gneiss showed a grey color that was slightly orange.

For each surface analyzed, values were obtained for four points. Table 2 summarizes the examples of values obtained for one of these four points for some of the surfaces. The other values not shown in the table followed the same trends. However, it is important to note this is a monochromatic trend, and therefore there is no direct relationship between the obtained color and the color seen with the naked eye, since the stones are heterochromatic.

Table 2. Lab * parameters for the analyzed samples.

\begin{tabular}{|c|c|c|c|c|c|c|c|c|}
\hline \multirow{2}{*}{ Samples } & \multicolumn{4}{|c|}{ Altered/Substitute Stone Parameters } & \multicolumn{4}{|c|}{ Standard Stone Parameters } \\
\hline & $\mathbf{L}$ & a & $\mathbf{b}$ & G & $\mathbf{L}$ & a & $\mathbf{b}$ & G \\
\hline Substitute Gneiss (torch top) & 67.5 & 2.05 & 7.77 & 1.30 & 61.4 & 3.62 & 16.0 & 0.70 \\
\hline Substitute Gneiss (parapet) & 65.7 & 0.42 & 5.94 & 1.00 & 55.3 & 5.07 & 15.3 & 0.50 \\
\hline Original Gneiss (external wall, light staining) & 56.8 & 0.22 & 4.83 & 0.50 & 57.4 & 1.43 & 12.9 & 0.80 \\
\hline Lioz limestone (torch) & 74.3 & 1.77 & 6.98 & 1.50 & 73.4 & 1.99 & 8.44 & 0.80 \\
\hline
\end{tabular}

${ }^{*}$ Lab: $\mathrm{L}=$ Brightness, $\mathrm{a}=$ red/green coordinate $(+\mathrm{a}$ indicates red and $-\mathrm{a}$ indicates green) and $\mathrm{b}=$ yellow $/$ blue coordinate $(+\mathrm{b}$ indicates yellow and $-\mathrm{b}$ indicates blue), showing in Figure 6; $\mathrm{G}=$ Gloss.

\subsection{Plate Characterization}

XRF analyses were performed at three different points on the connection plate (Figure 10), and the results indicated lead $(\mathrm{Pb})$ as the major element. Such a result was expected, since $\mathrm{Pb}$ was widely used by Master Valentim in his works. Furthermore, smaller levels of aluminum (Al) and silicon (Si) were verified, as well as traces of other elements. The values derived from the analyses ranged from $77.8 \%$ to $88.9 \%$ for lead oxide (PbO), $4.4 \%$ to $10.0 \%$ for silicon oxide $\left(\mathrm{SiO}_{2}\right)$, and $1.9 \%$ to $3.7 \%$ for aluminum oxide $\left(\mathrm{Al}_{2} \mathrm{O}_{3}\right)$. 


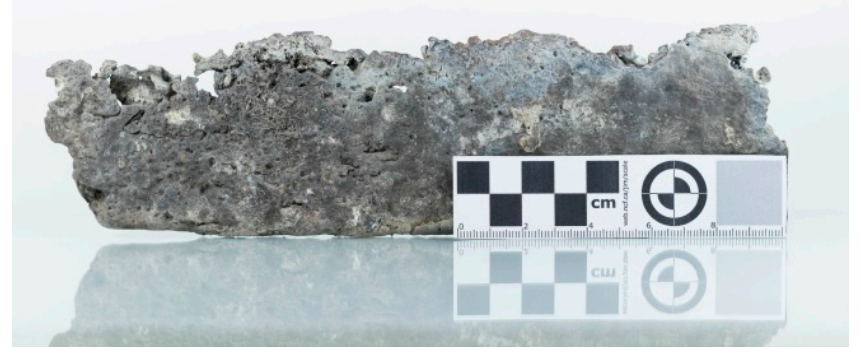

Figure 10. Lead plate used to connect the stone blocks of the monument.

\subsection{Light Stains Characterization}

The XRF analysis performed on the light stains (Figure 11) indicated a high content of lead $(\mathrm{Pb})$ and silicon (Si).

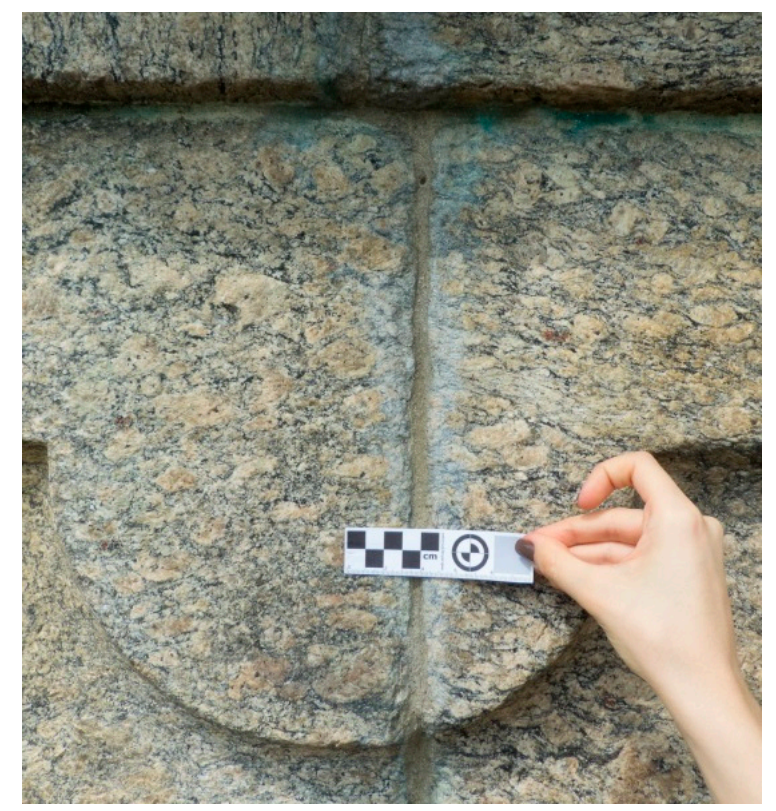

Figure 11. Light staining area on a Gneiss block.

The levels observed were approximately $50 \% \mathrm{~Pb}, 38 \% \mathrm{Si}$, and $8 \% \mathrm{Al}$, besides other elements. These results suggest that these stains may have originated from the association of the lead of the plates used to connect the blocks with other elements such as sulfur (from the pollution present in the environment of high urban movement), forming an insoluble salt of white coloration.

The XRD analysis demonstrated the presence of quartz, plagioclase, K-feldspar, and mica, as expected for Gneiss stones. However, such analysis also showed peaks of cerussite $\left(\mathrm{PbCO}_{3}\right)$, and anglesite $\left(\mathrm{PbSO}_{4}\right)$, which are the probable cause of the light stains, as well as insignificant peaks of cotunnite $\left(\mathrm{PbCl}_{2}\right)$.

Figure 12 shows the SEM image zoom of the staining area of the analyzed samples. The SEM-EDX results identified peaks of chlorine $(\mathrm{Cl})$, potassium $(\mathrm{K})$, carbon $(\mathrm{C})$, sulfur $(\mathrm{S})$, calcium $(\mathrm{Ca})$, oxygen $(\mathrm{O})$, iron $(\mathrm{Fe})$, sodium $(\mathrm{Na})$, magnesium $(\mathrm{Mg})$, silicon $(\mathrm{Si})$, and lead $(\mathrm{Pb})$. Quantitative analysis indicated about $65 \% \mathrm{~Pb}$. In order to verify the possible elements related to $\mathrm{Pb}$ in the light staining area analyzed, elemental mapping of $\mathrm{Pb}, \mathrm{S}, \mathrm{C}$, and $\mathrm{Si}$ was performed in Figure 13. 


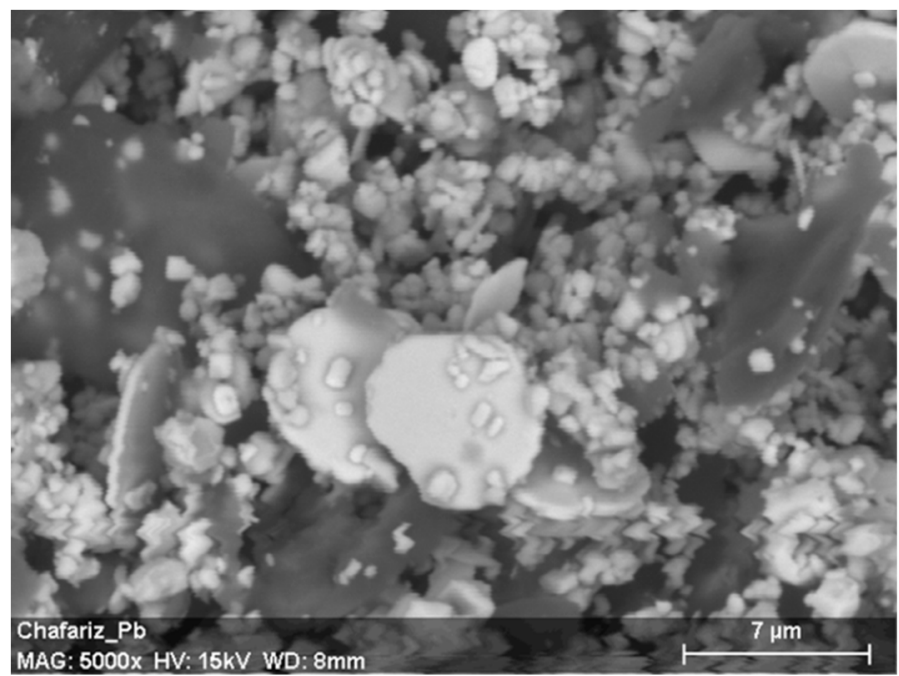

Figure 12. SEM image zoom of the staining area.
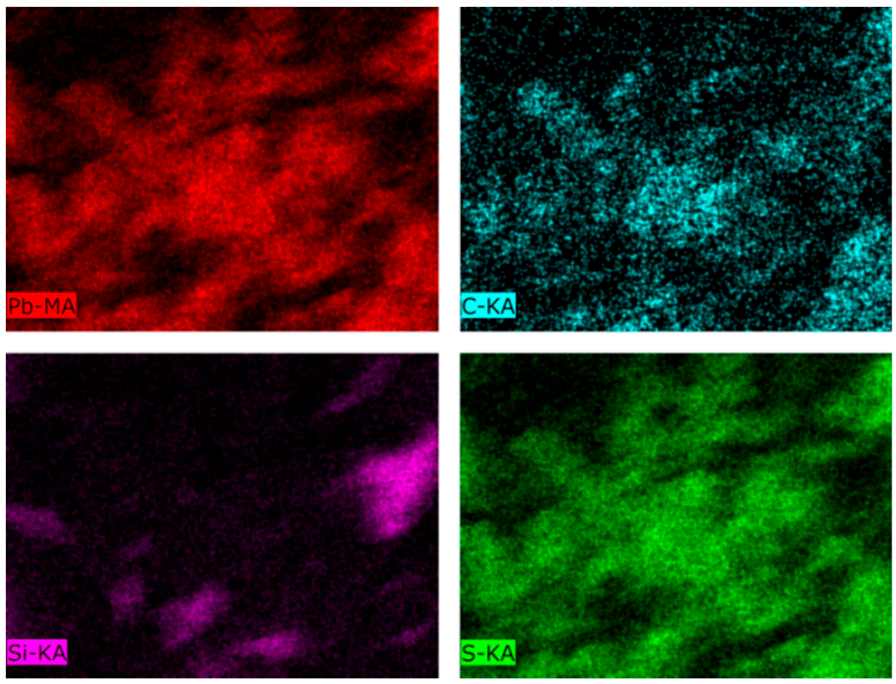

Figure 13. Elemental mapping of $\mathrm{Pb}, \mathrm{C}, \mathrm{Si}$, and $\mathrm{S}$, individually.

SEM-EDX investigation confirmed the presence of lead, sulfur, and carbon on the light staining area. Elemental mapping suggested that sulfur is the main element associated to lead. Therefore, it is possible that the light stains are $\mathrm{PbSO}_{4}$. The sulfur pollution emanating from vehicles was deposited on the surface of the fountain, and this element was associated with the lead used as a grout, forming the stable salt of lead sulphate.

Such results suggest that sulfur is the main element associated to lead. It is also possible to observe association between $\mathrm{Pb}$ and $\mathrm{C}$, but occurring to a lesser extent when compared to $\mathrm{S}$.

The results of ATG (Figure 14) indicated that the sample concerning change in the fountain is related to $\mathrm{PbSO}_{4}$ formation, since the thermal degradation curve is similar to this pure salt. Thus, it was believed that the sulfur pollution emanating from vehicles was deposited on the surface of the fountain, and that this element was associated with the lead used as a grout, forming the stable salt of lead sulphate.

Alterations in dimension stone monuments in several parts of the world have been observed by several authors [34-43], but all are related to $\mathrm{NaCl}$ efflorescence or the action of black crusts. In no case was there reported white patches caused by the action of sulfate or atmospheric carbonate with lead used as a grouting of the blocks of stone, generating a stable white salt capable of staining all the rock. 


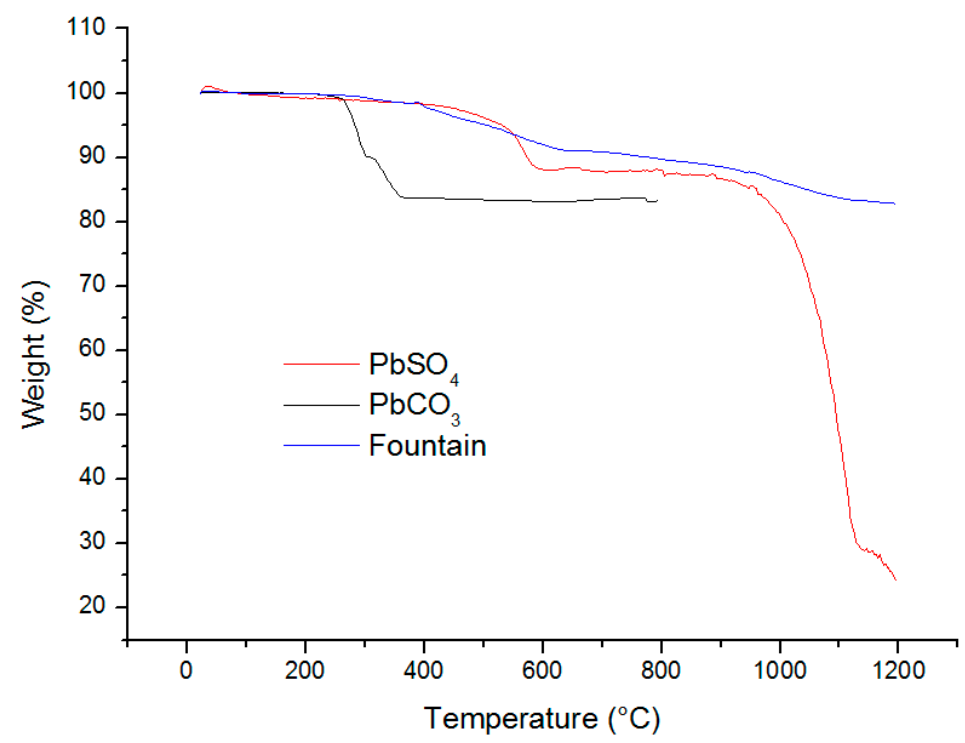

Figure 14. Thermal degradation curve showing the losses in each step with a rate of $10^{\circ} \mathrm{C} / \mathrm{min}$.

\section{Conclusions}

The rock of the fountain indicated $3.36 \%$ and $1.45 \%$ for porosity and water absorption, respectively, and the presence of quartz, plagioclase, K-feldspar, mica, zircon, and titanite. However, for the light staining area, analysis also indicated the presence of cerussite $\left(\mathrm{PbCO}_{3}\right)$ and anglesite $\left(\mathrm{PbSO}_{4}\right)$.

The results indicated that the gneiss fountain presents alterations characterized by white spots that are lead $\mathrm{PbSO}_{4}$, formed by the reaction of sulfur from pollution with lead used as a grout in the construction.

SEM-EDX investigation confirmed the presence of lead (65\%), sulfur, and carbon on the light staining area. Elemental mapping suggested that sulfur is the main element associated to lead. Therefore, it is possible that the light stains are $\mathrm{PbSO}_{4}$, which was confirmed in ATG investigation.

In the future we intend to study methods of cleaning the fountain to remove stains without affecting the surface of the stones, since $\mathrm{PbSO}_{4}$ is only removed with acid attack.

Author Contributions: Conceptualization and Methodology, R.C.d.C.R.; Formal Analysis, P.M.F.d.F. and D.S.B.; Results interpretation, R.C.d.C.R. and P.M.F.d.F.; Writing-Original Draft Preparation, P.M.F.d.F. and R.C.d.C.R.; Writing-Review, D.S.B. and R.C.d.C.R.

Funding: This research received no external funding.

Acknowledgments: The authors acknowledge the Centre for Mineral Technology (CETEM) for its infrastructure support, and the Brazilian National Council for Scientific and Technological Development (CNPq) for its financial support.

Conflicts of Interest: The authors declare no conflict of interest.

\section{References}

1. ARQGUIARio. Available online: http://arqguia.com/obra/chafariz-do-mestre-valentim/?lang=en (accessed on 12 June 2018).

2. Rio de Janeiro Aqui. Available online: http://www.riodejaneiroaqui.com/pt/chafariz-da-piramide.html (accessed on 12 June 2018).

3. IPHAN. Available online: http:/ / portal.iphan.gov.br/ans.net/tema_consulta.asp?Linha=tc_hist.gif\&Cod= 2974 (accessed on 12 June 2018).

4. Thought Co. Available online: https://www.thoughtco.com/rococo-art-architecture-4147980 (accessed on 12 June 2018). 
5. Telles, A.C.S. Atlas dos Monumentos Históricos e Artísticos do Brasil. Available online: http://portal. iphan.gov.br/uploads/publicacao/ColObrRef_AtlasMonumentosHistoricosArtisticosBrasil.pdf (accessed on 12 June 2018).

6. Brusadin, L.; Quites, M. A técnica da escultura em madeira com máscara de chumbo policromada: A contingência dos Cristos da Paixão da Ordem Terceira do Carmo de Outro Preto (MG). Visualidades 2016, 14, 188-215. [CrossRef]

7. Baptista, A.P. Debret's Rio de Janeiro Castro Maya Collection; Museus Castro Maya: Rio de Janeiro, Brazil, 2015; p. 128.

8. Mansur, K.L.; Carvalho, I.S.; Delphim, C.F.M.; Barroso, E.V. O gnaisse facoidal: A mais carioca das rochas. Anuário IGEO 2008, 31, 9-22.

9. Öztrürk, I. Alkoxysilanes Consolidation of Stone and Earthen Building Materials. Master's Thesis, University of Pennsylvania, Philadelphia, PA, USA, 1992.

10. Winkler, E.M. Stone in Architecture Properties Durability, 3rd ed.; Springer: Berlin, Germany, 1997.

11. Shiavon, N. BSEM study of decay mechanisms in urban limestone. Eur. Cult. Herit. 1992, 6, 35-46.

12. Torök, A.; Rosgonyi, N. Morphology and mineralogy of weathering crusts on highly porous oolitic limestones, a case study from Budapest. Environ. Geol. 2004, 46, 333-349. [CrossRef]

13. Sabbioni, C. Contribution of atmospheric deposit to the formation of damage layer. Sci. Total Environ. 1995, 167, 49-55. [CrossRef]

14. Fronteau, G.; Thomachot, C.S.; Chopin, E.; Barbin, V.; Mouze, D.; Pascal, A. Black-Crust Growth and Interaction with Underling Limestone Microfacies. In Natural Stone Resources for Historical Monuments; Geological Society of London: London, UK, 2010; Volume 333, pp. 25-34.

15. Matthieu, A.; Hérbert, R.; Menéndez, B.; David, C.; Bigas, J.P. Influence of Temperature and Salt Concentration on the Salt Weathering of A Sedimentary Stone With Sodium Sulphate. In Natural Stone Resources for Historical Monuments; Geological Society of London: London, UK, 2010; Volume 115, pp. $193-199$.

16. Bakolas, A.; Biscontin, G.; Moropoulou, A.; Zendri, E. Characterization of structural byzantine mortars by thermogravimetric analysis. Thermochim. Acta 1998, 321, 151-160. [CrossRef]

17. Chiarelli, N.; Miriello, D.; Bianchi, G.; Fichera, G.; Giamello, M.; Memmi, I.T. Characterization of ancient mortars from the S. Niccoló archaeological complex in Montieri (Tuscany Italy). Constr. Build. Mater. 2015, 96, 442-460. [CrossRef]

18. Gleize, P.; Motta, E.; Silva, D.; Roman, H. Characterization of historical mortars from Santa Catarina (Brazil). Cem. Concr. Compos. 2009, 31, 342-346. [CrossRef]

19. Moropoulou, A.; Bakolas, A.; Bisbikou, K. Characterization of ancient, byzantine and later historic mortars by thermal and X-ray diffraction techniques. Thermochim. Acta 1995, 269, 779-795. [CrossRef]

20. Moropoulou, A.; Bakolas, A.; Bisbikou, K. Investigation of the technology of historic mortars. J. Cult. Herit. 2000, 1, 45-58. [CrossRef]

21. Biscontin, G.; Birelli, M.P.; Zendri, E. Characterization of binders employed in the manufacture of Venetian historical mortars. J. Cult. Herit. 2002, 3, 31-37. [CrossRef]

22. Freidin, C.; Meir, I. Byzantine mortars of the Negev Desert. Constr. Build. Mater. 2005, 19, 19-23. [CrossRef]

23. Zeng, Y.; Zhang, B.; Liang, X. A case study and mechanism investigation of typical mortars used on ancient architecture in China. Thermochim. Acta 2008, 473, 1-6. [CrossRef]

24. Adriano, P.; Silva, A.S.; Veiga, R.; Mirao, J.; Candeias, A. Microscopic characterisation of old mortars from the Santa Maria Church in Évora. Mater. Charact. 2009, 60, 610-620. [CrossRef]

25. Budak, M.; Akkurt, S.; Bke, H. Evaluation of heat treated clay for potential use in intervention mortars. Appl. Clay Sci. 2010, 49, 414-419. [CrossRef]

26. Sanjurjo-Sánchez, J.; Trindade, M.; Blanco-Rotea, R.; Garcia, R.B.; Mosquera, D.F.; Burbidge, C.; Prudêncio, M.I.; Dias, M.I. Chemical and mineralogical characterization of historic mortars from the Santa Eulalia de Bóveda temple, NW Spain. J. Archaeol. Sci. 2010, 37, 2346-2351. [CrossRef]

27. Martínez, I.; Castillo, A.; Martínez, E.; Castellote, M. Physico-chemical material characterization of historic unreinforced masonry buildings: The first step for a suitable intervention. Constr. Build. Mater. 2013, 40, 352-360. [CrossRef]

28. Lezzerini, M.; Legnaioli, S.; Lorenzetti, G.; Palleschi, V.; Tamponi, M. Characterization of historical mortars from the bell tower of St. Nicholas Church (Pisa, Italy). Constr. Build. Mater. 2014, 69, 203-212. [CrossRef] 
29. Maria, S. Methods for porosity measurement in lime-based mortars. Constr. Build. Mater. 2010, 24, $2572-2578$. [CrossRef]

30. Nazdar Ink Technologies. Available online: https:/ /www.nazdar.com/en-us/News-events/ArtMID/4165/ ArticleID/224 (accessed on 12 June 2018).

31. Marques, E.A.G.; Barroso, E.V.; Menezes Filho, A.P.; Vargas, E.A., Jr. Weathering zones on metamorphic rocks from Rio de Janeiro-Physical, mineralogical and geomechanical characterization. Eng. Geol. 2010, 111, 1-18. [CrossRef]

32. National Research Council. Conservation of Historic Stone Buildings and Monuments; The National Academies Press: Washington, DC, USA, 1982.

33. Frazão, E.B.; Farjallat, J.E. Características tecnológicas das principais rochas silicáticas brasileiras usadas como pedras de revestimento. In I Congresso Internacional de Pedra Natural; FIL/ AIP: Lisboa, Portugal, 1999; pp. 47-58.

34. Delgado-Rodrigues, J. Conservation of granitic rocks with application to the megalithic monuments. conclusions report. In Degradation and Conservation of Granitic Rocks in Monuments; Vicente, M.A., Delgado-Rodrigues, J., Acevedo, J., Eds.; European Commission: Brussels, Belgium, 1996; pp. 161-242.

35. Feilden, B.M. Conservation of Historic Buildings; Reed Edcuational and Porfessiornal Publish: Oxford, UK, 1994.

36. Giacomelli, V.; Perego, G. II Degrade della Pietra in Basilica de San Pietro, Restauro e Conservazione; ENI: Roma, Italy, 1999; pp. 108-123.

37. Gobbi, G.; Zappia, G.; Sarbbioni, C. Sulphite quantification on damaged stones and mortar. Atmos. Environ. 1998, 32, 783-798. [CrossRef]

38. Gonzáles-Messones, F.L. La Interpretación de los Ensayos de Caracterización de la Piedra Natural, en el Marco de la Nueva Normativa Europea. In Curso de Rochas Ornamentais. Recife. CD-ROM. 2002. Available online: http:/ / mineralis.cetem.gov.br/bitstream/cetem/1201/1/Cap.III.part.1.pdf (accessed on 12 October 2018).

39. Gupta, A.S.; Rao, S. Weathering effects on the strength and deformational behavior of crystalline rocks under uniaxial compression state. Eng. Geol. 2000, 56, 357-374. [CrossRef]

40. Perry, S.H.; Duffy, A.P. The short-term effects of mortar joints on salt movement in stone. Atmos. Environ. 1997, 31, 1297-1305. [CrossRef]

41. Theoulakis, P.; Moropoulou, A. Microstructural and mechanical parameters determining the susceptibility of porous building stones to salt decay. Constr. Build. Mater. 1997, 11, 65-71. [CrossRef]

42. Viles, H.A. Urban Air Pollution and the Deterioration of Buildings and Monuments. In The Global Environment: Science, Technology and Management; Brune, D., Chapman, D.V., Gruynne, M.D., Pacyna, J.M., Eds.; Wiley-VCH: Weinheim, Germany, 1997; pp. 599-609.

43. Fitzner, B.J. Investigation of weathering damage on stone monuments. Geonomos 2016, 24, 1-15. [CrossRef] 